\title{
Perspective on 2015 DoD Cyber Strategy
}

\section{Addendum}

\author{
Lara Schmidt
}

RAND Office of External Affairs

CT-439/1

February 2016

Document submitted on February 23, 2016 as an addendum to testimony presented before the House Armed Services Committee on September 29, 2015

This product is part of the RAND Corporation testimony series. RAND testimonies record testimony presented by RAND associates to federal, state, or local legislative committees; government-appointed commissions and panels; and private review and oversight bodies. The RAND Corporation is a nonprofit research organization providing objective analysis and effective solutions that address the challenges facing the public and private sectors around the world. RAND's publications do not necessarily reflect the opinions of its research clients and sponsors. RAND ${ }^{\circledR}$ is a registered trademark. 
For more information on this publication, visit www.rand.org/pubs/testimonies/CT439z1.html

Published by the RAND Corporation, Santa Monica, Calif.

(C) Copyright 2016 RAND Corporation

RAND $^{\circledR}$ is a registered trademark

\section{Limited Print and Electronic Distribution Rights}

This document and trademark(s) contained herein are protected by law. This representation of RAND intellectual property is provided for noncommercial use only. Unauthorized posting of this publication online is prohibited. Permission is given to duplicate this document for personal use only, as long as it is unaltered and complete. Permission is required from RAND to reproduce, or reuse in another form, any of its research documents for commercial use. For information on reprint and linking permissions, please visit www.rand.org/pubs/permissions.html.

The RAND Corporation is a research organization that develops solutions to public policy challenges to help make communities throughout the world safer and more secure, healthier and more prosperous. RAND is nonprofit, nonpartisan, and committed to the public interest.

RAND's publications do not necessarily reflect the opinions of its research clients and sponsors.

\section{Support RAND}

Make a tax-deductible charitable contribution at www.rand.org/giving/contribute

www.rand.org 


\title{
QFR submitted by Shuster, Bill \\ House Committee on Armed Services \\ Outside Perspectives on the Department of Defense Cyber Strategy \\ Tuesday, September 29, 2015
}

\begin{abstract}
Question for Dr. Lara Schmidt: In your written testimony, you addressed DoD shortfalls in both recruiting and retention of the cyber workforce. Oftentimes, financial incentives are cited as the potential solution to these shortcomings. I agree with your statement that retention is closely linked to job satisfaction, so my question is whether DoD's human capital management system is effective in placing the cyber workforce into positions that provide sufficient skill utilization and job satisfaction?
\end{abstract}

Answer: I have not conducted a formal analysis of the extent to which the Department of Defense's (DoD's) approach to cyber workforce management succeeds in placing civilians and service members into jobs for which they are qualified. Furthermore, I am unaware of any such assessment for workforce management approaches following the new initiatives DoD unveiled in 2015. ${ }^{1}$ However, the work undertaken as part of the National Initiative for Cyberspace Education (NICE) Cyberspace Workforce Framework, ${ }^{2}$ which identifies the required skills for many cyberspace jobs, is a necessary first step toward performing any "job analysis" to evaluate the extent to which personnel matched to jobs possess the required skills to work effectively. Both receiving the right training (initial and continuing) and progressing through different jobs that draw on similar skill sets are important to ensuring personnel are well matched to job requirements.

I am also unaware of any formal analyses of job satisfaction among DoD's civilian and military cyberspace cadres. Conventional wisdom asserts that DoD offers its personnel unique opportunities to serve the nation and conduct high-stakes, highly dynamic operations they would find no place else; as a result, conventional wisdom asserts that job satisfaction is high. While this assertion rings true for some DoD cyberspace jobs (e.g., military personnel conducting offensive and defensive operations), I question the wisdom of applying such logic to DoD cyberspace jobs that both (a) require staff to manage a high operational tempo and other stressors on family and personal time (e.g., frequent changes of duty location and/or organizations) and (b) are similar to jobs conducted in the private sector (i.e., lack the "only in DoD" allure). Therefore, an assessment of job satisfaction in the "IT-like" DoD Information Network Operations (DoDIN Ops) job

\footnotetext{
${ }^{1}$ Department of Defense, Cyberspace Workforce Management, Directive 8140.01, August 11, 2015.

${ }^{2}$ NICE, National Cybersecurity Workforce Framework, Washington, D.C.: Department of Commerce, 2013. The services have adopted this framework to varying extents.
} 
categories may be illuminating, as it may not adhere to conventional wisdom. Commercial-sector IT job satisfaction has been linked to the existence of defined career paths that allow growth and progression not only through advancement into the management ranks, but also through technical tracks that allow personnel to continue to learn, engage with professional peer groups, and innovate to keep pace with rapidly changing technology. 